\title{
O TEXTO PUBLICITÁRIO NA SALA DE AULA: MAIS UMA OPÇÃO DE LEITURA
}

\author{
Dioni Maria dos Santos Paz
}

\begin{abstract}
A transmissão de significados constitui o fluxo intersubjetivo pelo qual circula a cultura. A experiência vivida, o real sentido, percebido ou compreendido, o mundo do real ou do imaginário, das teorias científicas ou dos mitos, enfim, da vigília ou do sonho, é mediado de homem a homem por entes concretos capazes de impressionar nossos sentidos: os signos. (Isaac Epstein).
\end{abstract}

\section{CONSIDERAÇÕES INICIAIS}

O objetivo deste artigo é levar para a sala de aula o texto publicitário como uma modalidade de leitura persuasiva, que, dentro de uma tipologia textual generalizada, segundo Eni Orlandi (1987), faz parte do discurso autoritário. Procurar-se-á mostrar, na leitura dos índices textuais e contextuais, as implicações da intencionalidade nas estratégias argumentativas utilizadas, bem como destacar alguns recursos retóricos e icônicos que caracterizam a linguagem da propaganda.

Todo ensino comprometido com o exercício da cidadania deve criar situações para que o aluno possa desenvolver sua competência discursiva. Um dos aspectos dessa competência é o sujeito ser capaz de utilizar a língua de modo variado, para produzir diferentes efeitos de sentido e adequar o texto a diferentes situações de prática oral e escrita. É o que se chama de competência lingüística, ou seja, conhecimento que o falante ou ouvinte, escritor ou leitor possuem sobre a língua e o utilizam para a construção de expressões que compõem os textos. Além disso, também é relevante a competência estilística, que é a capacidade de o sujeito entender ou escolher, dentre os recursos expressivos da língua, os que mais se adaptam às condições de produção, ao destinatário e às finalidades do texto e ao gênero textual escolhido.

Nessa perspectiva, urge contemplar nas atividades de ensino-aprendizagem a diversidade de textos e gêneros, não apenas em função de sua importância social, mas também pelo fato de que textos são organizados de formas diferentes. Por esse motivo, a necessidade de atender à classe estudantil obriga à revisão de métodos de ensino e à constituição de práticas que dêem ao aluno uma competência discursiva capaz de satisfazê-lo em todas as instâncias de interação que se apresentarem a seus olhos. 


\section{O DISCURSO DA PUBLICIDADE OU PROPAGANDA}

Segundo Sandmann (1997), em português, o termo publicidade é usado para a venda de produtos ou serviços e propaganda tanto para a propagação de idéias como no sentido de publicidade. Propaganda parece ser o termo mais abrangente. Portanto, usaremos neste estudo os dois termos indistintamente, embora o corpus a ser analisado se constitua de textos de caráter comercial.

O texto publicitário é resultado da união de vários fatores: psicológicos, sociais e econômicos, como também do uso de efeitos retóricos e icônicos aos quais não faltam as figuras de linguagem, as técnicas argumentativas e os mecanismos de persuasão entre outros.

Brown (1971) afirma que a publicidade ou propaganda usa esquemas básicos a fim de obter o convencimento dos receptores. São eles:

a) o uso de estereótipos - esquemas e fórmulas já consagradas. Tem-se como exemplo uma pessoa bem vestida e de boa aparência, induzindo à idéia de pessoa bem-sucedida e de modelo a ser seguido. Aparecem também estereótipos lingüísticos escolhidos para persuadir. Por exemplo: "Povo unido, jamais será vencido" ou "Mês de maio, mês das mães". A característica maior do estereótipo é não permitir perguntas, visto ser como uma verdade conhecida;

b) a substituição de nomes - trocam-se termos com a intenção de influenciar positiva ou negativamente determinadas situações. Geralmente, usam-se eufemismos, por exemplo, em vez de dizer que "o capitalismo vai mal", diz-se que "é preciso reaquecer a livre iniciativa"; em vez de dizer que "os Sem-terra ocuparam as terras ", diz-se que "os Sem-terra invadiram as terras";

c) a criação de inimigos - neste caso, o discurso autoritário persuasivo cria inimigos mais ou menos imagináveis. Temos exemplos nos comerciais de produtos de limpeza ou germicidas, que colocam como inimigos os germes ou fungos, ou mesmo nos comerciais de sabão em pó, que vêem na sujeira o inimigo oculto. Pode também 
aparecer como inimigo um produto concorrente. É o caso dos comerciais de produtos ou propagandas políticas que se referem a algo ou alguém como ruim ou desonesto;

d) o apelo à autoridade - apelo à fala ou procedimentos de especialistas em determinados assuntos, por exemplo, do dentista que afirma que determinada pasta de dente é melhor do que as outras, porque possui determinados componentes que combatem a cárie e o tártaro, ou do atleta que usa determinado tênis, porque é mais resistente e possui amortecedores que protegem o tornozelo e o pé;

e) a afirmação ou repetição - sabe-se que a vacilação é inimiga da persuasão. Então, usa-se a certeza em forma de imperativo para não deixar dúvidas. Os verbos têm o poder de conduzir a vontade do receptor. Temos exemplos nas afirmações: "Use OMO", "Compre sempre sandálias havaianas".

\section{PROPAGANDA E IDEOLOGIA}

Ao nos valermos do texto publicitário como uma alternativa de leitura, devemos ponderar que esse tipo de discurso tem como objetivo provocar reações emocionais no receptor. Por isso, esse texto utiliza recursos retóricos para convencer ou alterar atitudes e comportamentos. Para tanto, as palavras, no contexto, passam a indicar ideologias e o modo de conduzi-las é de enorme importância para o efeito de argumentação.

Segundo Peirce (1975), o signo é algo que representa outra coisa e que é interpretado por alguém de acordo com a ideologia desse alguém. Sabe-se que um produto ideológico faz parte de uma realidade natural ou social que reflete uma outra realidade que the é exterior. Assim, tudo que é ideológico possui um significado e remete a algo situado fora de si. Bakhtin (1979) defende que é impossivel afastarmos o estudo dos signos do estudo das ideologias, e que a questão do signo se prolonga na questão das ideologias. Existe uma relação de dependência tão grande que se pode crer que só é possível o estudo das idéias e valores contidos nos discursos, atentando para a natureza dos signos que os constroem. Portanto, os recursos retóricos que entram na organização de um texto, não seriam meros recursos formais, 
só para embelezar a frase, mas revelariam muitos comprometimentos de cunho ideológico.

Para Fiorin (1988), ideologia é uma visão de mundo, e existem tantas visões de mundo quantas forem as classes sociais, porém a ideologia dominante é a ideologia da classe dominante. Complementando, Sandmann (1997) afirma que a linguagem da propaganda é até certo ponto reflexo e expressão da ideologia dominante, dos valores em que se acredita, pois ela manifesta a maneira de ver o mundo de uma sociedade em certo espaço da história.

Nessa conjuntura, a escola tem um papel relevante para a formação do hábito de leitura em qualquer parâmetro da sociedade. Basta identificar os interesses dos alunos às várias formas de leitura. É claro que se o professor está comprometido com uma proposta de leitura transformadora de educação, ele encontra no dia-a-dia recursos favoráveis à consecução de seus objetivos. Assim o educando estará apto a ler o mundo seja ele verbal ou não-verbal.

Abordando a questão da leitura de mundo sob outro ângulo, professor e alunos poderiam se perguntar que aspirações humanas a linguagem da propaganda procura alimentar, satisfazer ou de que aspirações ela procura vir ao encontro.

Segundo Peninon (1976), quando se analisa uma mensagem publicitária que se apresenta à nossa percepção e à nossa interpretação, leva-se em conta um conjunto organizado de imagens e proposições que se identificam com algo. Esse manifesto nos remete a um produto, a um serviço, a uma marca ou a uma instituição determinada. Essa mensagem pode partir da linguagem, da imagem ou de ambos.

Também, pode-se classificar essas mensagens, não em função de seus conteúdos, mas conforme as diferentes ordens a que pertencem, nos seguintes tipos:

a) mensagens que dependem do código formal de reconhecimento de gênero: tratase de mensagens de identidade publicitária de informação. É o plano da identificação e tem uma função classificatória. É fundamental, pois está encarregada de garantir o reconhecimento do caráter publicitário da informação; 
b) mensagens que dependem do plano da denotação: trata-se das diferentes mensagens informativas inscritas no texto e na imagem. Tem uma função identificadora, pois assegura os autores do manifesto e tem uma característica pedagógica a respeito do produto. Além disso, compreende o conjunto do texto lingüístico para fundamentar a proposição publicitária. Tem, também, a função de relacionar os destinatários. A mensagen icônica se encontra nesse item. Em primeiro lugar, seu objetivo será o de informar; em segundo lugar, será o da representação simbólica, isto é, o de significar. Mediador obrigatório do sentido, a mensagem da denotação se converte, então, em fonte de mensagem inferencial de conotação;

c) mensagens que dependem do plano da conotação: trata-se das diferentes mensagens adicionais, inferíveis do plano da denotação e que auxiliam no plano geral da significação. Sua função é axiológica e empática (mensagem psicológica).

\section{A INTENCIONALIDADE COMO MARCA DO TEXTO PUBLICITÁRIO}

O texto publicitário mostra que há uma interação entre aquele que argumenta e o outro, pois as convicções do primeiro objetivam modificar ou reforçar as idéias do segundo. Comprova-se, assim, que um enunciador tem, além do objetivo de informar, o de orientar o receptor em relação a determinadas conclusões, orientação está presente na própria estrutura lingüística do enunciado.

$\mathrm{Na}$ análise dos componentes do texto publicitário, o estudo da argumentação permite verificar sua influência na manipulação dos elementos lingüísticos e icônicos direcionados para a persuasão. Assim, o texto manifesta-se como um traço da intenção projetada de um emissor para um receptor, a fim de comunicar uma mensagem e produzir um efeito.

Ao ensinar como produzir ou ler um texto publicitário, o professor deve deixar bem claro que na elaboração do mesmo existe uma textualização de informações pela qual um emissor realiza intenções num processo de seleção e de concatenação de elementos escolhidos para determinadas situações. Assim, pode-se descrever a produção de textos como um processo de decisões regulados pela intenção do produtor. 
O professor deve também esclarecer que a argumentação consiste num jogo de signos em que o emissor emprega estratégias para dissimular a sua intenção e manipular o destinatário. Dessa maneira, o texto constitui uma grande força de poder persuasivo, pois orienta o modo de querer, pensar e agir do receptor. Da mesma forma, deve-se levar em conta a função social da mensagem, pois ao comunicar-se o homem estabelece relações com os outros, esperando respostas e comportamentos.

Outro aspecto a ser observado é que existem marcas lingüísticas e formais que apontam uma direção no texto e que concorrem para a determinação do estilo. Isso significa que a intencionalidade também concorre para a existência de marcas formais que definem o estilo do texto. Desse modo, o funcionamento discursivo tem uma determinada estrutura e a atividade de interpretação, que está em ação a todo momento na comunicação, funda-se na suposição de que quem comunica tem determinadas intenções.

Comprova-se, mais uma vez, que toda a estratégia publicitária é de natureza persuasiva em maior ou menor grau e que "a argumentação é uma atividade estruturante do discurso, pois é ela que marca as possibilidades de sua construção e Ihe assegura a continuidade." (Koch,1987, p. 159).

\section{CARACTERÍSTICAS DA LINGUAGEM DA PROPAGANDA}

A mensagem publicitária para ser eficiente tem a necessidade de difundir determinada marca criando-lhe uma imagem clara e duradoura. Para Citelli (1985), essa mensagem precisa ser correta para persuadir o consumidor a preferir uma marca em detrimento de outra, motivando-o a comprar o produto. Portanto, despertar a atenção, o interesse, o desejo de compra, levando o receptor a comprar o produto é o objetivo principal do emissor. Para isso, a propaganda para produzir resultados positivos, deve cumprir corretamente a sua função de comunicar e informar. Isso significa que se deve levar em conta os seguintes aspectos: se causou impacto e despertou o interesse (difundiu); se despertou o desejo de possuir o produto ou serviço (persuadiu); se incutiu credibilidade e levou à compra (motivou).

Observa-se que a mensagem publicitária é um conjunto de idéias transmitidas ao receptor através de um conjunto de mídias. Segundo Jakobson (1971), para ser eficaz deve estar dirigida à audiência -alvo o que significa conhecer as necessidades 
desse público, suas expectativas em relação ao produto e a linguagem cabível a ser empregada.

Na comunicação oral, compõe-se de palavras, música e sons; na comunicação visual, essencialmente do texto lingüístico e da imagem (ilustração e cor); e na comunicação audiovisual é constituída pelas duas primeiras mais o movimento.

Em se tratando de texto publicitário científico, o aspecto mais relevante a ser abordado é que as afirmações gerais devem ser evitadas. Quanto mais específica e definida for a mensagem maior e melhor será a força dos argumentos empregados. Portanto, a mensagem nunca deve mentir, principalmente porque terá um público receptor informado e eficiente.

Se entendermos que existem características específicas para o estilo propagandístico ou publicitário, entendendo-se como estilo as marcas próprias desses textos, verificaremos que há muitas especificidades na construção desse tipo de gênero textual. Uma das características é a organização em frases curtas e muitas vezes incompletas, dando margem à imaginação do leitor. Por exemplo, "Neston Barra. Sua academia de bolso. Neston. Mil maneiras de ser saudável." (Superinteressante, maio de 2001). Pode-se observar que esse traço estilístico é bastante freqüente no texto publicitário. É claro que as variedades de estilo têm a capacidade de sugestionar e emocionar mediantes determinados processos e efeitos. Nem sempre seguem as normas padrões, pelo contrário, tentam agredir a linguagem com desvios que chocam e chamam atenção.

Além dessa característica, segundo Sandmann (1997), podem-se registrar aspectos especialmente criativos, com destaque aos chamados desvios gramaticais. São eles:

a) variação lingüística - adaptação da fala ou da escrita ao contexto ou situação. Mais formal, menos formal, coloquial, científica, gíria, etc. Por exemplo: "Pense mais em você, sua bobona." (Desfile, março de 1991)

b) empréstimo lingüístico - uso de termos ou expressões estrangeiras no lugar de termos da língua materna. Por exemplo: "No Big shopping center, você encontra várias griffes". (Encarte promocional, dezembro de 2000) 
c) aspectos ortográficos - jogos com a grafia em que se pretende causar efeitos expressionais, com a função de valorizar as letras ou chocar com as palavras. Por exemplo: "Paralização dos servidores técnico-administrativos da UFSM". (Cartaz, julho de 2001)

d) aspectos fonológicos - brincadeiras com a rima, o ritmo, a aliteração e a paronomásia, procurando salientar 0 aspecto poético do som das palavras. Por exemplo: “Pick up FORD, raça FORTE” (Comercial de TV, 2001)

e) aspectos morfológicos - emprego de cruzamentos vocabulares, prefixações, sufixações, abreviações, etc., para compor uma nova palavra ou para realçar a intensidade ou aumento do sentido. Por exemplo: "Passe na Pampeiro e compre seu zerinho." (Comercial de TV, 2001)

f) aspectos sintáticos - uso de combinações típicas da linguagem da propaganda, tais como, recursos estilísticos ou expressivos com simplicidade estrutural. Por exemplo: "Pensou cerveja, pediu Brahma” (Comercial de TV), ou “Um fica o tempo todo na água. O outro nã0 sai”. (Loção protetora solar NIVEA, Cláudia, janeiro de 2001)

g) aspectos semânticos - emprego da polissemia ou ambigüidade. Jogos com as palavras para entreter o destinatário, desafiá-lo a entender a mensagem e prender sua atenção. Por exemplo: "Relógio que atrasa, não adianta. Classifolha. Pontualmente toda quinta, sábado e domingo". (Folha, setembro de 1991), ou "Isso é da sua conta. Tudo que você precisa saber sobre o seu banco". (Folheto Bamerindus)

h) aspectos contextuais - composição do texto publicitário: título, texto e assinatura. São as informações sobre quem produz o texto e o assunto a ser tratado. Por exemplo: "Não deixe a natureza ir embora" (título). "Pássaros, plantas e animais que sempre habitaram nossas florestas estão sendo extintos ou isolados em pequenas manchas verdes...." (texto). Instituto Ambiental Vidágua e Fundação S.O.S. Mata Atlântica (assinatura). (Superinteressante, maio de 2001) 


\section{OS ALUNOS E A LEITURA DE TEXTOS PUBLICITÁRIOS}

Ao professor de língua portuguesa cabe a tarefa de motivar os alunos para a produção e a leitura de textos. Um dos princípios do estudo com o gênero publicitário é mostrar que as estratégias de produção desse tipo de texto estão amparadas nos recursos retóricos e icônicos de persuasão. Para tanto, deve-se ensinar que a propaganda é um apelo, um vínculo entre o anunciante e o consumidor.

Vestergaard e Schröder (1988) afirmam que o emissor não pode ignorar o receptor e a propaganda será tanto mais eficaz quanto ela disser ao público aquilo que ele precisa saber e aquilo que ele deseja saber. O conteúdo da mensagem (idéias) é constituído a partir do momento em que se define o argumento que irá estimular o consumidor. Só assim surgirão argumentos objetivos e subjetivos.

Para se definir os argumentos objetivos é preciso partir-se de informações exatas (dadas pelas pesquisas), só então deve ser feita a seleção dos signos lingüísticos. A pesquisa de seleção parece ser fácil, mas agora é que vem a questão: quais os recursos retóricos a serem usados para estimular o interesse por um serviço ou a compra de um produto?

Além dos recursos estilísticos e criativos vistos acima, entram aqui os conhecimentos lingüísticos, tais como:

a) a seleção lexical, objetivando uma linguagem direcionada a um determinado público, com termos específicos, claros e concisos. Por exemplo: "Pais habilidosos merecem o maior incentivo. Dê Bosch de presente. "(Encarte do dia dos pais das lojas Ponto Frio - agosto de 2001)

b) o uso de tempos verbais (principalmente o imperativo), persuadindo com a forma direta do verbo (compre, use, lave, limpe, viaje, etc.). Por exemplo: "Ligue e assine um jornal completo." (Zero Hora, julho de 2001)

c) o uso de escalas e operadores argumentativos (até, inclusive, aliás, já, também, mas, etc.), levando o receptor a adotar definições. Por exemplo: 
"Tantas opções, com estes preços, só no Ponto Frio." (Encarte do dia dos pais das lojas Ponto Frio - agosto de 2001)

d) o emprego de figuras de linguagem (metáforas, metonímias, hipérboles, etc.), para fazer comparações, relações ou ativar o conhecimento prévio. Por exemplo: "Os modelos e as condições que você tanto desejava estão esperando por você no coração do Rio Grande. Venha logo buscar o seu Renault." (A Razão, julho de 2001)

e) o uso de modalizadores (com certeza, necessariamente, é preciso, acredito que, etc.), para sinalizar o modo de quem fala ou escreve frente ao que declara. Por exemplo: "Ford Ka. Certamente rápido, muito rápido." (Superinteressante, julho de 2001)

É claro que os argumentos objetivos, por si só, não bastam, pois é preciso mostrar vantagens do ponto de vista do consumidor. Aqui é que entram os argumentos subjetivos que consistem em saber quais serão as reações do receptor. Portanto, é de importância capital o professor e os alunos identificarem o que o imaginário consumidor pensa a respeito do produto a ser oferecido. É necessário conhecê-lo em suas características geográficas, demográficas e psicológicas para após a definição do tema, dirigir sua linguagem a esse público específico.

Outro aspecto relevante é que a linguagem publicitária faz uso também dos signos não-verbais ou icônicos como uma grande força de expressão e persuasão. Em alguns casos, a ilustração é auto-suficiente para conseguir os objetivos que se pretende obter. Em outros, ela só não basta, então é necessário recorrer aos signos não-verbais. Apesar disso, na história publicitária é possível notar a importância, sempre crescente, concedida à ilustração, demonstrada pelo percentual que ocupa no conjunto do espaço útil do anúncio ou quaisquer peças gráficas.

Tendo presente que a ilustração exerce papel de muita importância, é necessário que os alunos aprendam a fazer leituras semióticas sobre a imagem, que, segundo Joly (1996), tem tanta importância quanto um texto verbal. Para isso, o 
professor deve elucidar que os signos icônicos servem para reforçar os valores de atenção, compreensão, memorização e credibilidade do texto.

Como fator de atenção, a ilustração colocada junto ao título é um fixador da vista. A cor é o primeiro elemento da ilustração susceptível de atrair a visão. Cada cor pode atuar pela tonalidade, claridade, saturação, superfície que ocupa e contraste com as cores vizinhas, principalmente o fundo. A forma exterior é o segundo elemento de atenção.

Como fator de compreensão, a ilustração destina-se a facilitar o entendimento do texto. Para isso, serve-se de uma parábola, uma metamorfose, uma alegoria entre outros. Temos exemplos nas propagandas de colchão, que mostram as pessoas dormindo tranqüilas.

Como fator de memorização do anúncio, a ilustração contribui para a identificação do produto, isto é, para distingui-lo dos produtos concorrentes e calcá-lo na memória do leitor, favorecendo as associações de idéias com o conhecimento prévio, conhecimento partilhado ou conhecimento de mundo. Temos exemplos nos comerciais de bebidas como da Coca-Cola, Antártica, Brahma, etc.

Como fator de credibilidade, a ilustração se destina a mostrar o resultado da ação do produto. Temos exemplos nos comerciais de sabão em pó, em que as roupas são lavadas para mostrar o antes e o depois do uso do produto.

É importante frisar que enquanto algumas pessoas acreditam no que está impresso, uma grande maioria acredita no que vê, e não precisa ser uma prova científica, mas apenas uma aparência da prova de verdade que se quer transmitir.

Podem-se distinguir, assim, algumas funções pertinentes à semiótica da ilustração:
a) aumentar o índice de atenção do anúncio;
b) tornar o anúncio mais aprazível à vista;
c) induzir à leitura do texto;
d) estimular o desejo pelo produto anunciado;
e) engrandecer o produto anunciado;
f) demonstrar ou reforçar afirmações feitas no texto; 

g) identificar o produto ou a marca;
h) formar atmosfera adequada.

Observa-se que a ilustração desperta o desejo pelo objeto anunciado através do seu poder de evocar idéias e lembranças, pela sua faculdade de despertar sensações, e acima de tudo pelo estímulo sutil, de ordem emotiva, que desencadeia os interesses que são as molas da ação.

Juntamente com a ilustração, o material auxiliar, o logotipo, a marca e o espaço em branco formam os aspectos gráficos de um anúncio ou de uma peça gráfica. Devese lembrar que não só a linguagem como também a psicanálise usa o inconsciente como fonte de formação do discurso. É interessante estabelecer, analogicamente, o nível de relacionamento que há entre sujeito e linguagem. O que importa é trabalhar no limite do texto levantando-se as suas verdades escondidas através de técnicas que objetivam salientar o inconsciente humano nele (texto) contido.

Como se pode notar há um estreito relacionamento entre signo, ideologia, intencionalidade e determinação da construção do discurso persuasivo. Nessa proporção, percebe-se que a linguagem da propaganda se dota de signos marcados pela superposição, isto é, são signos colocados como expressão de verdades que tem como fim último convencer ou alterar comportamentos já estabelecidos.

Para fazer uma boa leitura do discurso publicitário, tanto o professor quanto o aluno deverão estar conscientes de que a técnica publicitária parece baseada no pressuposto de que um texto publicitário chamará mais a atenção quanto mais violar as normas cultas. Para isso, ambos deverão conhecer os padrões da gramática tradicional para poder brincar com os desvios e subversões de um sistema que já deve ser do conhecimento de todos.

Se você, professor, é um profissional consciente e inovador, na certa já está pensando em realizar tarefas com os textos publicitários ou já realizou algum tipo de exercício visando a explorar os elementos da linguagem publicitária. Minha proposta de atividade está calcada na leitura, podendo também ser aplicada nas aulas de produção de texto. 
Quero deixar bem claro que cada vez mais se torna necessária a atualização dos professores no que se refere à capacidade de trabalhar em sala de aula com textos da mídia, pois são esses textos que fazem o dia-a-dia dos alunos e da sociedade em geral. Portanto, o papel da escola, na formação do aluno como sujeito capaz de transformar seus horizontes de conhecimento de mundo, começa pela leitura de mundo que rodeia esse sujeito social.

\section{LEITURA DE UMA PROPAGANDA}

A análise em questão objetiva abordar aspectos relevantes, porém não pretende ser exaustiva. Destacam-se, pois, elementos mais ostensivos que permitam uma visão geral da leitura da propaganda. A escolha recaiu sobre um texto da revista Veja do dia 19 de abril de 2000, que faz uma propaganda da revista Veja na Sala de Aula.

\section{(imagem indisponível)}

Este texto está composto de elementos icônicos e retóricos. Primeiramente, vamos analisar a iconicidade. É a imagem de uma foto do Movimento dos Sem-Terra (MST). O grupo está com bandeiras vermelhas com o símbolo do movimento a favor da reforma agrária no país, e uma faixa, um pouco tapada por componentes que estão caminhando na frente, em que se pode deduzir que esteja escrito o lema: Luta nacional: Reforma agrária e justiça.

A imagem apresenta como pano de fundo um lindo céu azul e um campo verde, contrastando com um ônibus amarelo, estacionado no campo, onde está escrito "Escolar". Sabe-se que o azul, o verde e o amarelo são cores que fazem parte da bandeira brasileira. A propaganda procura implicitar que a luta pela terra também faz parte de uma luta nacional.

Aproximando a imagem, vemos um contingente de pessoas simples vestindo camisetas e calções de todos os tipos como se vestissem roupas arrecadadas de campanhas de agasalho. A maioria usa boné, com o logotipo do MST, ou chapéu de palha e chinelo de dedo. São pessoas humildes que reivindicam um pedaço de chão 
para plantar e sobreviver neste Brasil com tanta terra sem produção. Nota-se que estão em ritmo de caminhada à beira de uma estrada.

A ilustração é bem colorida e chamativa. Tem a função de aumentar o índice de atenção do leitor. Além disso, a gravura com o ônibus escolar tem a função de mostrar e reforçar a afirmação de que a revista Veja tem caráter informativo e esclarecedor no âmbito escolar. Outra função pertinente à ilustração é que ela ajuda a formar uma atmosfera adequada ao objetivo geral da propaganda. No caso, no uso da revista Veja na Sala de Aula.

Esses recursos icônicos estão insinuando que a revista Veja está inserida no contexto da luta dos trabalhadores, bem como é uma aliada dos leitores, alunos e professores, sobre as informações de caráter social e político. Percebe-se também que a ilustração é quase auto-suficiente para vender uma idéia, pois o ônibus escolar, a fila dos Sem-Terra e o quadro verde com a frase Veja na Sala de Aula. Indispensável como a educação expressam um conjunto de informações que levam ao uso da revista na sala de aula como meio de atualização e formação dos alunos e professores. Portanto, a expansão dos símbolos utilizados no texto, tornam explícitas as referências implícitas.

Dando seqüência na leitura, vamos analisar os aspectos retóricos, iniciando-se pelos contextuais:

Título: Leve seus alunos para dentro da notícia.

Subtítulo: Veja na sala de aula. Levando a notícia para 1600 escolas.

Texto: Ajude seus alunos a manter o caderno sempre atualizado. Veja na Sala de Aula é uma maneira inteligente e inovadora de estudar por meio de reportagens de Veja....

Assinatura: Revista Veja do dia 19 de abril de 2000. Site: www.veja.com.br

Agora, vamos pormenorizar os aspectos retóricos. No título e subtítulo, observamos a simplicidade estrutural que faz parte do texto publicitário. Foram empregadas frases curtas e de efeito: "Leve seus alunos para dentro da notícia." O imperativo leve foi usado em tom de ordem, persuadindo de forma direta o leitor. $A$ expressão para dentro da notícia faz um jogo com a expressão já referida para dentro da sala de aula. Isso possibilita causar um efeito de assimilação: notícia $X$ sala de aula, que será reforçada com a inclusão das frases "Veja na Sala de Aula. Levando a 
notícia para 1600 escolas." Esse dado confirma a verdade do uso da revista por parte das escolas.

Feita a leitura do título e do subtítulo, passemos ao texto maior que contém mais argumentos para convencer a escola, os professores e os alunos a usarem a revista como recurso indispensável de informação e cultura.

O corpo maior do texto inicia com a seguinte frase: "Ajude seus alunos a manter o caderno sempre atualizado." Nota-se o verbo ajude no imperativo. Essa ordem, juntamente com o operador argumentativo sempre, reforça a necessidade do apoio dos professores e da responsabilidade que os mesmos têm de manter o aluno atualizado. O texto continua aludindo ao nome Veja, para firmar a possibilidade de aceitação pela constante repetição: "Veja na Sala de Aula é uma maneira inteligente e inovadora de estudar por meio das reportagens de Veja." Agora, a seleção lexical está calcada em dois qualificadores: inteligente e inovadora. Além dessas qualificações, encontramos a circunstância de meio: por meio das reportagens de Veja. Isso mostra que o caminho a ser utilizado para estudar de forma inteligente e inovadora é através da leitura das reportagens dessa revista.

Seguindo a leitura, encontramos uma frase bastante extensa, como se fosse uma notícia a ser dada ao leitor: "Hoje, 1600 escolas com ensino médio já estáo recebendo toda semana um pacote especial contendo exemplares da revista Veja para os alunos e para o professor, Guias do Professor que trazem dicas e orientações de como utilizar as notícias de Veja nas diferentes disciplinas." Podemos notar que o léxico foi selecionado para culminar com uma persuasão convincente, pois os dados manifestam argumentos verídicos.

Primeiramente, encontramos a circunstância de tempo Hoje para registrar que atualmente esse procedimento é realizado e que se trata de uma ótima novidade de recurso didático nas escolas. Inclusive o dado de 1600 escolas com o operador argumentativo já acompanhado da locução verbal estão recebendo afirma a notícia que está sendo transmitida. Os recursos de argumentação são reforçados com o quantificador toda acompanhado do sintagma semana e da escolha dos campos semântico selecionados. Um relacionado à escola: alunos, sala de aula, escola, caderno, estudar, ensino médio, professor, Guias do Professor, dicas, orientações, disciplinas, aprendem; e outro relacionado à revista: Veja, notícias, reportagens, pacotes, exemplares, dicas, brindes editoriais, pôsteres temáticos, edições especiais, 
atualidade. Essa escolha reforça a idéia da combinação entre a escola e a leitura da revista.

Outro recurso argumentativo está no uso dos operadores argumentativos $E$ ainda, que iniciam uma oração coordenada com sentido de adição. Eles poderiam ser substituídos por além disso, além do mais, e também, para dar a idéia de vantagem ao assinante da revista, com brindes editoriais, pôsteres temáticos e edições especiais de Veja.

Para concluir o texto, é criada uma frase com o verbo novamente no imperativo "Adquira Veja na Sala de Aula para sua escola". Essa escolha verbal pretende levar definitivamente o leitor à compra do produto, justificada com a seguinte conclusão:" assim, seus alunos aprendem com a atualidade, ficam melhor preparados e podem até acabar virando notícia." Podemos notar que a intenção final do produtor da propaganda é mostrar os benefícios gerais da aquisição da revista Veja na Sala de Aula. Para isso, foi usado o intensificador melhor, para dar a idéia de competência dos alunos, e reforçada essa competência com o uso dos operadores argumentativos e até, para mostrar a possibilidade de inclusão dos mesmos no contexto das notícias, pois com a leitura dos textos encontrados na revista qualquer aluno, professor ou escola podem virar notícia.

A presente análise tentou mostrar um recorte na amplitude do fenômeno que é o gênero publicitário, visando a detectar sua relação com a intencionalidade e a persuasão. Com isso, pretendeu-se exibir mais um tipo de leitura que poderá fazer parte do repertório do professor e seus alunos. Desse modo, fica claro que ao se fazer Lingüística do Texto procura-se examinar o que compõe e caracteriza o texto em questão.

\section{CONSIDERAÇÕES FINAIS}

Com o estudo feito, pode-se deduzir que a publicidade não é só uma modalidade original da consciência das coisas. Descrita através de uma estética do mundo cotidiano ou de uma forma poética da matéria manufaturada, é também um excitador do apetite dos diversos produtos de consumo. Para isso ela se apóia em três funções básicas: difundir determinada marca, produto ou serviço, associando-a a uma imagem pretendida, cuja finalidade é despertar o interesse do público alvo; 
persuadir o receptor, convencendo-o e criando uma preferência; motivar o consumidor, levando-o à ação de compra, através da credibilidade.

Fica evidente que a estrutura publicitária comporta uma argumentação icônicolingüística com o objetivo de persuadir o consumidor, levando-o à ação de compra. Ao explorar as emoções básicas do ser humano e utilizar técnicas argumentativas para atrair a atenção do receptor, destaca-se o objetivo comercial.

Um lembrete deve ser passado aos profissionais que lidam com diferentes turmas: é muito importante escolher o texto de acordo com o nível de leitura dos alunos e preparar atividades pertinentes ao programa da disciplina. Caberá também ao professor, organizar uma seleção geral do que pretende desenvolver durante as unidades de trabalho. Assim, poderá aproveitar diferentes tipos de textos publicitários em diferentes conteúdos programáticos, adequando-os ao nível de suas classes e aos objetivos que pretende alcançar. Outro aspecto importante a ser lembrado é que o professor deve conscientizar os alunos da importância do conhecimento dos mecanismos do uso da linguagem com artimanhas persuasivas, a fim de que o mesmo possa usufruir ou defender-se desse tipo de manipulação.

\section{BIBLIOGRAFIA}

BAKHTIN, Mikhail. Marxismo e filosofia da linguagem. São Paulo:Hucitec,1979.

BROWN, J.A.C. Técnicas de persuasão. Rio de Janeiro: Zahar, 1971.

CITELLI, Adilson. Linguagem e persuasão. São Paulo: Ática, 1985.

EPSTEIN, Isaac. O signo. 2.ed. São Paulo: Ática, 1986.

FIORIN, J. L. Linguagem e ideologia. São Paulo: Ática,1988.

JAKOBSON, R. Lingüística e comunicação. São Paulo: Cultrix, 1971.

JOLY, M. Introdução à análise da imagem. Campinas: Papirus, 1996.

$\mathrm{KOCH}$, Ingedore V. Argumentação e Linguagem. 2.ed. São Paulo: Cortez,1987.

ORLANDI, Eni. A linguagem e seu funcionamento: as formas do discurso. 2.ed. Campinas: Pontes, 1987.

PEIRCE, C. S. Semiótica e filosofia. São Paulo: Cultrix, 1975. 
PENINON, Georges. Semiotica de la publicidad. Barcelona: Gustavo Gili, 1976.

SANDMANN, A. J. A linguagem da propaganda. 2.ed. São Paulo: Contexto, 1997.

VANOYE, F. Usos da linguagem. 2.ed. São Paulo: Martins Fontes, 1981.

VESTERGAARD, T., SCHRÖDER. A linguagem da propaganda. São

Paulo:Martins Fontes, 1988. 